\title{
The Rise of Transportation and Logistics in Europe 1950 - 2000
}

\author{
Richard Vahrenkamp
}

Additional information is available at the end of the chapter

http://dx.doi.org/10.5772/45800

\section{Introduction}

In the last decades logistics changed fundamentally: from a microeconomic point of view, logistics developed from an auxiliary function in materials management to an independent factor of production that would go onto coordinate world-wide supply chains. From a macroeconomic point of view, the rise of the logistics sector as an important employment sector is fundamental and a force for deepening the division of labor. This paper explores the driving factors of the rise of logistics. It demonstrates how traffic policy of a gradually unified Europe shaped the development of logistics from its basic functions of transport, handling of cargo, and storage to the modern concepts of high performance logistics, including concepts of organization of world wide supply chains and dimensions of quality in services, such as promptness and accuracy. Besides the political factor of the unification of Europe, one can identify an economic factor concerning the development of a consumer-oriented economy. The great variety of consumer goods was a challenge for the automobile production and the distribution logistics. As a third factor, the innovations in the parcel industry are considered where for the first time the flow of goods are linked to information technology to ensure speed and quality resulting in the "tracking and tracing technology". The forth factor was the process of globalization, which led to the creation of production sites for consumer goods outside of Europe. As a result, the logistics of consumer goods distribution were realigned to import harbors, where consumer goods arrived pooled in shipping containers. The paper is based on the evaluation of research reports, monographs on traffic policy and national and European statistics. The rise of logistics has not drawn much attention of the scholars in the past. So this paper opens a new field of research. First we address to the consumer-oriented economy.

The decades of the economic miracle in Western Europe after 1950, also called "trente glorieuses" or "miracolo economico", mark an evolution of the consumer-oriented economy in Europe, which not only addresses mass consumption but also the mass production and mass 
distribution of consumer goods (Strasser 1998). Mass production, mass distribution and mass consumption constitute a system. The automobile industry and the automobile trade, which form the basis of mass mobilization, play an important role within the consumer goods industry. The automobile cannot be viewed as only an important consumer good, but also as a product which enabled purchases in distant central markets and the comfortable transport of large amounts of consumer goods. It created the precondition for the focus on large scale entities in the retail trade. Other strong sectors of the consumption-based economic system are banking services, insurance services and services of the tourist industry. However, those sectors are less important for the supply of goods and are therefore neglected in this research.

\section{Mass motorization and the motorway network}

In the decades following 1950, mass motorization strongly contributed to the economic miracle in Western Europe. ${ }^{1}$ Automobile stock rose rapidly. In Western Germany, the growth rates of the 1950s amounted to $20 \%$ per annum. Mass motorization got a fresh impulse from the reasonably priced, iconographic starter models: in Italy the Fiat 500, in France the Citroen 2CV, and in Western Germany the VW Beetle. The existing road system, which in many European countries did not include motorways, was unable to sustain the increasing motorization. There was said to be chaos and accidents on the roads. ${ }^{2}$ (Girnth, 1954). In response to the insufficient road network and the increasing influence of the auto lobby on traffic policy, European countries gradually extended the motorway network, which unburdened the roads and crosstown links and promised fast and comparably safe driving (Mom 2005, Ross 1998, p. 86). The following table shows extension of the motorway network in the EU15 countries.

\begin{tabular}{|l|c|c|c|c|c|}
\hline Country/Year & $\mathbf{1 9 6 0}$ & $\mathbf{1 9 7 0}$ & $\mathbf{1 9 8 0}$ & $\mathbf{1 9 9 0}$ & $\mathbf{1 9 9 8}$ \\
\hline Belgium & 183 & 488 & 1.203 & 1.631 & 1.682 \\
\hline Denmark & - & 84 & 516 & 601 & 861 \\
\hline Germany & 2.671 & 6.061 & 9.225 & 10.809 & 11.427 \\
\hline Spain & - & 387 & 2.008 & 4.693 & 8.269 \\
\hline France & 174 & 1.533 & 5.264 & 6.824 & 9.303 \\
\hline Ireland & - & - & - & 26 & 103 \\
\hline Italy & 1.065 & 3.913 & 5.900 & 6.193 & 6.453 \\
\hline Luxemburg & - & 7 & 44 & 78 & 115 \\
\hline Netherland & 358 & 1.209 & 1.780 & 2.092 & 2.360 \\
\hline Austria & - & 478 & 938 & 1.445 & 1.613 \\
\hline Portugal & - & 66 & 132 & 316 & 1.252 \\
\hline Finland & - & 108 & 204 & 225 & 473 \\
\hline Sweden & - & 403 & 850 & 939 & 1.339 \\
\hline United Kingdom & 202 & 1.183 & 2.683 & 3.180 & 3.421 \\
\hline
\end{tabular}

Source: Eurostat (2002a, p.1). Data for 1960 from World Road Congress (1969, p.51).

Table 1. Length of the motorway network in the EU15 in kilometers

\footnotetext{
${ }^{1}$ For Sweden see Lundin (2004, p. 303-337). For Italy see Paolini (2005). For Germany see Klenke (1993). For France see Loubet (2001). For Great Britain see Thoms et al. (1998).

${ }^{2}$ We define motorways in this paper as junction-free roads with two lanes for each direction.
} 


\section{The logistical function of motorways in the consumer-oriented economy}

The extension of the motorway network has not only served the automobile, but also the rapidity and economy of truck traffic. It gave a decisive impulse to the truck-based logistic systems. In the political debate about expansion of the highway system, two aspects - the transportation of people and the traffic of goods on the motorways - were viewed differently within European transport policy. In fact, German politics assigned goods transport to the railroad, and thereby pursued a twofold traffic policy: The motorway was mainly built for the automobile. However, this twofold traffic policy was short-sighted, as it did not address the economic rationalizing effects of truck traffic. Moreover, it impeded the development of logistics as a growing segment in the early phase of a service-oriented society: truck traffic decreased the costs and speeded up the transport of goods. In Germany, this aspect was not even considered in the research of economic effects of the motorway until $1970 .{ }^{3}$

In contrast to Germany, in Italy the aspect of rationalization of the goods traffic was one reason for the construction of motorways, and was appreciated as transport "modernization" since the railroad showed very poor performance (Bonino and Moraglio 2006). Capital investment in railway modernization focused on the area of passenger transportation, so that rolling material in freight haulage was no longer current. Moreover, the railway could not be integrated into a modern logistical concept of time-based competition, since the freight train did not run on schedule (Kerwer 2001, p. 173-216). In England, the construction of highways began with detour roads around the cities of Preston and Lancashire so that the cross-roads were cleared and goods traffic was accelerated. Charlesworth (1984, p. 35) shows the lobby work of the Chamber of Industry and Commerce.

The development of truck traffic along the European motorway network is closely related to the evolution of modern logistical systems. Those evolved in the two main areas of the consumer-oriented economy: in the just-in-time delivery concept for automobile assembly facilities and in the build-up of modern distribution structures in the retail trade for the turn-over of goods in the already developed consumer goods industry. The stores were supplied by hierarchical distribution systems that were composed of central and regional warehouses where the goods were stored. The warehouses together with the motorway developed to the essential infrastructure of the mass consumption society. For example, consider the motorway M1 in the UK linking London to Leeds. Its section from Milton Keynes (location of the warehouse of Amazon) to Nottingham developed to the preferred location for distribution logistics known as "golden triangle". ${ }_{4}$

If one includes the automobile industry into the branch of the consumer goods industry, one can assert the thesis that the consumer-oriented economy is based on modern logistics and

\footnotetext{
${ }^{3}$ See literature report by Frerich 1974.

${ }^{4}$ Merriman 2007, p. 203.
} 
vice versa. A consumer-oriented economy is characterized by a differentiated offer of mass customized goods in a consumer market where customers have a large choice of offers. The deliveries of goods are urgent. A rapid change of fashion and models on the consumer goods markets and time-based deliveries to the automobile assembly facilities require transports without delay. In European transport networks, this is only possible via truck, as door-to-door-transports without transfer, while the railway slackens in this system of time and quality competition.

The question concerning the development of distribution systems was put in context with the distribution of consumer goods, and was related to the expansion of department stores and the increasing presence of chain branches within the retail sector. For the first time, scientific marketing methods were implemented systematically in retail. Customer desires were to be scrutinized and, if necessary, sparked. Additionally, agile logistics had to deliver the goods to the store racks in time, in order to avoid empty racks which might cause antagonism and loss of customers, which is very easy on a consumer market that appears to have an almost unlimited offer of goods. This reveals a consumer orientation in modern logistics. In the academic theory of logistics, the location of production plants, as well as central and regional warehouses, was researched in order to minimize storage and transport costs and transport to the stores (ReVelle and Swain 1970).

The Western European the consumer-oriented economic system had a logistic structure that the following figure exhibits. ${ }^{5}$ With the exception of secured public or quasi-public sectors, the market economy regulated competition among producers of goods and service providers. The infrastructure of transport and storage capacity allows the supply of the goods required for production and the distribution of consumer goods. The consumer goods industry and especially the automobile industry were very well-developed. The logistics of the developed consumer goods markets could profit from a dense motorway network, to built-up structures of external suppliers in the automobile industry. The productive, truckbased distribution structures served the supply of a large variety of consumer goods. The railroad transported primarily goods for the heavy industries.

In addition, these infrastructure services lead to the structure of an economy based on the division of labor, which can exploit the learning curves and economies of scale provided by specialization.

\section{The automotive logistics of the automobile industry}

This section deals with the Europeanization of the automobile industry. It focuses on how the "automotive logistics" sector emerged. Growth and high earnings during the years of the economic miracle enabled the well-unionized work force of the automobile industry to implement high company tariffs. Management balanced high costs and affordable end products. The outsourcing of production and logistics into sectors and countries with lower wages served as a way out of the cost trap. In 1988, the average hourly wage amounted to 18

\footnotetext{
${ }^{5}$ For the structure of communist logistics see Vahrenkamp 2012.
} 
euros for industrial workers in Germany, compared to Portugal where the hourly rate amounted to 3 euros (Eurostat 1989, p. 126). The transfer of warehouse operations and production supply processes to low-wage employees of the logistics trade lowered costs. This was the starting point for the development of just-in-time-delivery and the outsourcing of parts production to low-wage countries in the 1980s (Christopher 2010). Both developments gave a strong boost to the logistics industry to create a "modern logistics", which extended the basic functions transport and storage with the aspect of quality: rapidity, punctuality, low error rates and process control with the help of computer networks were in demand. In logistics trade, the separate business segment "automotive logistics" was created, which complemented the classical logistic functions with services and production steps, such as inventory management and re-ordering, packaging, pricing and pre-assembly.

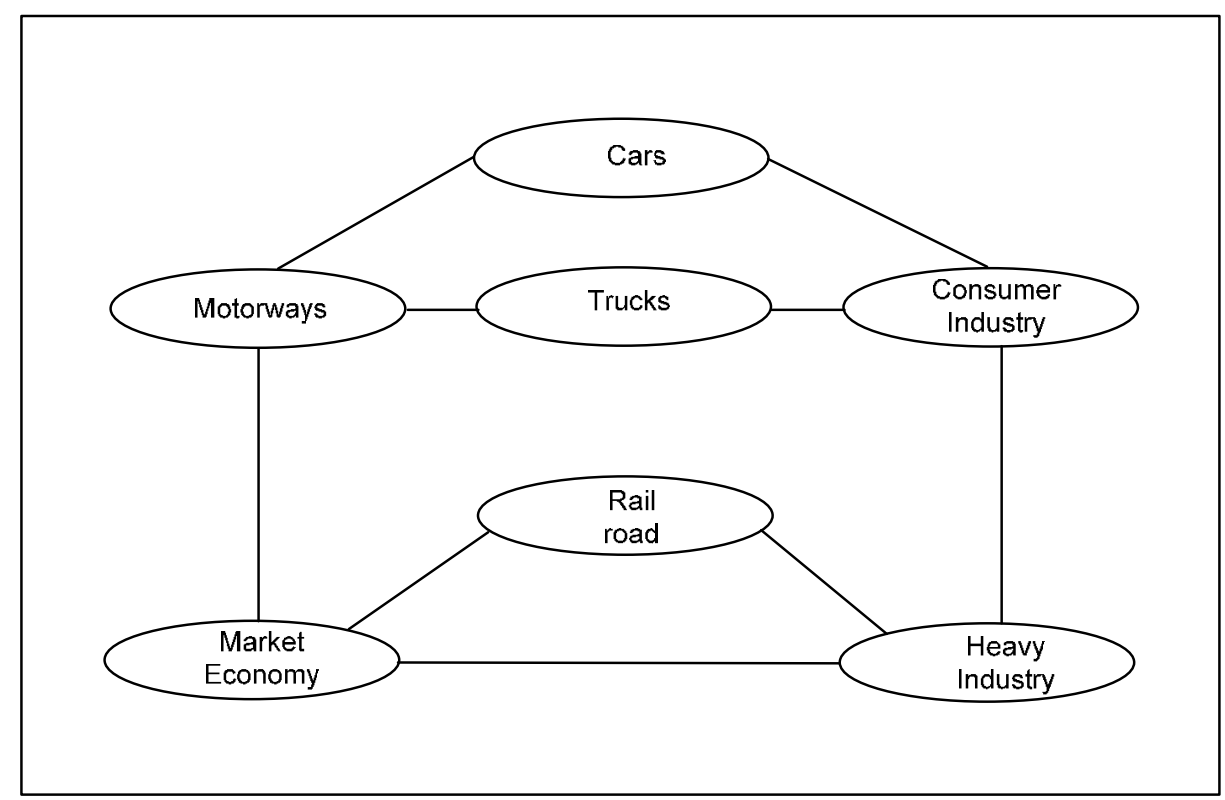

Figure 1. Model of the logistic structure of the consumer-oriented economic system.

\section{Common traffic policy in Europe and the liberalization of truck traffic}

Border-crossing road freight transport in Europe was only made possible via a number of international institutions and agreements. ${ }^{6}$ The Economic Commission Europe (ECE), which organized the commission for domestic traffic, needs to be mentioned. Already prior to 1949, this commission had been enabling truck traffic. This was thanks to its convention on road traffic (also called "Freedom of Road"). Foreign trucks obtained the right to enter a

${ }^{6}$ Regarding the following see Bundesminister für Verkehr 1961, part VII., Trinkhaus 1998, letter J., Frerich and Müller 2004. 
country with their freight, whereas before the convention, the cargo had to be shifted to a domestic truck at the border (Schipper 2007). The commission for domestic traffic coordinated the Marshall Plan's aid supply which started in 1948. It also represented a field of policy for road and truck traffic expansion in order to compensate the railroad capacity constraint which followed the war. On May 19, 1956, the commission established the transport contract within the international road haulage (CMR), and the customs agreement on the international goods transport in sealed trucks with carnets TIR on 15 January, 1959. Therefore, custom checks for border-crossing transit transports became redundant. After all, the European conference of traffic ministers (CEMT), which was founded in Brussels in 1953 by Italy, Belgium, France, Germany, and Switzerland, helped tremendously in coordinating traffic policy in Europe. ${ }^{7}$ It had the political goal of facilitating and easing the exchange of goods within Europe, and in 1960 it concluded an agreement at The Haag with respect to maximum size and weight of trucks.

Beside oversight of the European Economic Commission, there were bilateral agreements between two countries regarding the amount of truck allocations. These were determined annually by representatives of the Ministries of Transport. If the contingents were spent, there could be no further truck traffic. This shows how restrictive and inflexible traffic allocation system was, especially with regard to the constantly growing exchange of goods within the European Economic Community EEC.

The agreement for the foundation of the European Economic Community in 1957 aimed at developing a joint traffic policy to ease transnational goods traffic and to abolish barriers confronting the exchange of goods. The EEC agreement, under Title IV ("The traffic"), articles 70 to 84, required the coordination of European traffic policies. Conditions were to be formulated, under which traffic companies throughout the EEC were able to work. In particular, article 79 inhibits the discrimination of transport conditions based solely on the country of origin or country of destination (Trinkaus 1998, letter J211). ${ }^{8}$ Article 81 of the EEC agreement provides for a reduction in border taxes and fees. Articles 85 and 90 require free and fair competition in the economy, including the traffic sector. This was specified with the claim for free market access, the restraint of state subsidies, cartel bans, and the prohibition of abuse of power. However, it has been a long and difficult, 34-year way leading to the goal of a European-wide market with free access for transnational truck transport service.

What is most surprising about the EEC agreement is its clear market-based orientation, which differs tremendously from the economic and traffic policies of the individual member countries. At the peak of the Cold War, this orientation was to be understood more as an ideological differentiation to the Eastern bloc than a maxim for domestic policy. Moreover, it

\footnotetext{
7 An important step for Western Germany to overcome the foreign-policy isolation. The report of the „European Conference of Traffic Ministers" on 16 October , 1953 is published in the traffic paper 1954, p. 178-180. By now, all European states (except Serbia), including Russia, form part of the CEMT, also Azerbaijan and Turkey.

${ }^{8}$ An example fort the discrimination is the transport of 100 tons steel plate. The prices for transportation via railway for a distance of 253 kilometers from Duisburg to Bingen amounted to $610 \mathrm{DM}$ in July 1954 . However, the price for a comparably long, but transnational roadway of 252 kilometers from Liege to Duisburg accounted for 378 DM. See Bayliss 1965, p. 11.
} 
needs to be emphasized that the regulations of the EEC and the European Union referred to transnational traffic. Separately, each individual country can regulate its domestic traffic.

Traffic policy can draw on many instruments to regulate truck traffic. ${ }^{9}$ There are three categories of instruments: regulation of market access, price regulation and regulation of operation, while taxes for the operation of trucks, security standards for vehicles and drivers' working condition are set. If control of market access is reduced to subjective entrepreneur qualifications and if pricing is not subject to state requirements, this is considered liberalization of truck road haulage. In contrast, the operative regulation of truck road haulage is understood as the legal regulation of truck operation.

The common traffic policy of the EEC focused on truck traffic, which was easier to standardize than the area of railroads, since these were state monopolies. In order to implement the requirements of Title IV of the EEC agreement pertaining to truck traffic, the EEC council of ministers had two main fields of policy: the liberalization and the harmonization of the operative truck road haulage regulations. Liberalization guarantees market access for foreign entrepreneurs in the home country, and creates competition in the hitherto isolated national markets. In the 1960s, truck industry regulation in the EEC countries showed varying levels. The countries which used the railroad as an instrument for economic and social policy also combined regulation with a protection policy, restrictive licensing and price regulations. These countries include England, France, Belgium, and Germany. The Netherlands considered the transport sector as a regular economic sector without public obligations. Italy limited its railroad policy to a deficit settlement (Bayliss 1965, p. 64). Harmonization alludes to the unification of national operative regulations. Differences distort competition and hinder the creation of a common traffic market. In the field of harmonization, the EEC launched a number of regulations (European Commission 2001, part 3).

For decades, the EEC's council of ministers was unable to put the liberalization requirements of Title IV of the agreement into practice, since some of the member countries initially aimed at harmonizing the terms of competition within the EEC. Among the member countries, Germany and France were interested in railroad protection and used the broad harmonization policy to postpone liberalization. As a precondition, they combined liberalization with extensive harmonization. The Netherlands and England had already liberalized truck traffic at the end of the 1960s, and did not support railroad-friendly politics. Hence, a conflict between harmonization supporters and liberalization advocates developed ${ }^{10}$ (Frerich and Müller 2004, p. 128). According to 1983 estimates of the European commission, high railroad deficits influenced opinions on traffic policy in some member states and "initiated them to judge the politics towards other carriers mainly on the basis of their effect on the railroad". The commission suggested investigating road haulage for "further possibilities, how the supply could be adjusted to the demand, which made the present system for capacity checks unnecessary at the very end." (Europäische Kommission 1983, p. 6 and 12).

\footnotetext{
${ }^{9}$ The regulation appeared for the first time in the 1930s in all European countries, see Bayliss 1965.

${ }^{10}$ In England the market access and the pricing were liberalized since the 1960s, see Laaser 1991, p. 192).
} 
As the conflict between harmonization supporters and liberalization advocates in the Council of Ministers caused a blockade of traffic policy for years, the institutions of the EEC developed an unpredictable dynamic. On January 22, 1983, the European parliament filed suit against the Council of Ministers at the European Court of Justice for failure to act. On May 22, 1985, the European Court of Justice enunciated a judgment against the Council of Ministers for failure to act (Blonk 1985, p. 97). Between 1985 and 1986, the Council of Ministers made decisions for the liberalization of road haulage. The existing discrimination on the side of any third parties due to bilateral quotas of truck rides was abolished in January 1992 with the help of a progressive and noticeable increase in multilateral joint quotas. In 1990, the truck transport tariffs in transnational traffic, which were created to protect the railroad, were abolished and free market rates were enacted.

Compared to harmonization, which was subject to veto rule, liberalization was easier to achieve due to majority rule in the Council of Ministers. As a consequence, liberalization was realized without harmonization. For the establishment of equal market conditions, the important adjustment of truck taxes was not achieved until the turn of the millennium. In 1996, the tax burden for trucks without exhaustion gas cleaning in Europe ranged from 414 DM in Finland to 5,286 DM in Austria. ${ }^{11}$

As a result of liberalization, the truck fleet increased sharply to 15.7 million in the years between 1980 and 1990, and in 1998 reached just 20 million, whereas in the decade between 1970 and 1980, the number of trucks rose only by 3 million to 10.6 million. From 1990 to 1999 , traffic performance in the EU climbed from 790 to 1,258 billion tons kilometer. This included $76 \%$ of traffic within distinct member states (Eurostat 2002a, p. 1 and Tronet 2002). Liberalization lowered transportation costs due to strong competition within individual countries. This enabled commercial freight haulage to secure its market share between 1985 and 1995 against transport on own account ("private carriers"). in all EU countries except Italy and Portugal.

\section{The European Domestic Market as logistics promoter}

The establishment of the European Domestic Market on January 1, 1993, and the conversion of the EEC into the European Union (EU) involved the harmonization of fees, taxes, norms and regulations. Furthermore, it was characterized by the omission of border formalities for transnational freight haulage by truck. Until then, long delays at the borders were necessary for the compensation of various strict regulations in the member countries, which lead to long traffic jams for trucks. ${ }^{12}$ The detailed investigations of the Cecchini Commission revealed that trucking companies suffered a loss of $€ 8$ billion due to internal administrative costs and delays at the borders. This corresponded to approximately $2 \%$ of transnational goods value (Cecchini 1988). The waiting period reflected the processing of required

\footnotetext{
${ }^{11}$ Data according to the Federation of German Long-Distance Hauliers. One US-Dollar equaled about 2.50 DM in the 1980s.

${ }^{12}$ In 1986, at the motorway border crossing Kiefersfelden from Germany to Austria, the Federal Government considered a truck's hold of 1,200 meter length as necessary, see Bundestagsdrucksache 10/5908, p. 2.
} 
documents at the border. These documents were related to different sales taxes and excise taxes, as well as varied sanitary and veterinary regulations for consumables. Moreover, different technical norms fragmented the market and impeded free goods traffic. Since 1993, those barriers with the exchange of goods and services no longer apply, and trucks can cross the borders without stopping.

The establishment of the European Domestic Market involved the liberalization of truck transport and lent strong support to the restructuring of a Europe-wide logistics and to the intensification of European division of labor. Industry locations and supplier plants could be dislocated because of powerful logistics. While until 1993, distribution systems of producers or trading firms were organized as national entities in Europe, the EU then enabled transition to a transnational form of organization with centers of distribution that were able to supply entire regions internationally. This can be best seen in the metropolitan areas of London, Paris, Brussels and Cologne. There are in total approximately 80 million consumers represented - while the regions around Paris, Brussels, and Cologne is also called "blue banana" in transport geography. A central warehouse in Brussels or Lille can supply consumers in less than 24 hours with a truck-based supply network, making these locations very attractive for logistics in Europe. Since the opening of the Channel Tunnel ("Eurotunnel") in 1994 (Gourvish 2006), the former mining town of Lille, is located in the center of the metropolitan areas. The connection Calais-Folkstone is built up with a commuter rail which transports trucks piggy-back through the tunnel. The train ride from Lille through the Eurotunnel to London takes 90 minutes, to Paris 60 minutes, and to Brussels 30 minutes. The rides via truck are comparable. In 1998, the commuter rail transported 704,000 trucks (Deutsche Verkehrszeitung, 6 February 1999).

\section{Parcel services as pacemaker for the logistics industry}

The evolution from the industrial to the consumer-oriented society has increased the importance of valuable manufactured goods compared to bulk goods, and was noticeable in the 1970s due to the increasing volume of sent parcels throughout Europe. During liberalization of transport markets in the US in the 1970s and 1980s, the parcel services UPS and Federal Express were founded, which pretty soon focused on a global operating area. The parcel services have created the package with a limited weight and limited measurements as a special segment of the transportation business. They built a network of cargo airplanes for long-distance transport, which was independent of the freight capacity of passenger airplanes (belly freight) (Campbell 2001).

The parcel services were promoters and pacemakers of the whole logistics industry and, with various innovations, they have paved the way to high performance logistics. They have defined the basic parcel and introduced the objective of standardization to the transport industry. They have tightened transport, achieving domestic delivery within 24 hours, while traditional packaged goods networks show a delivery time of three days. They have implemented measures to guarantee the quality of service. They were one of the first industries to use barcodes, enabling the tracking and documentation of parcels within the 
system. In marketing, they introduced simple pricing models so that the customer could calculate the transport costs in advance. The complicated pricing models from the era of railroad logistics have been overcome.

Up to 2000, parcel services showed high growth rates. They acted as competitors in the packaged goods sector and made much cargo shift to the parcel segment.

\section{Globalization boosting logistics}

The process of globalization led to the creation of production sites for consumer goods outside of Europe. Due to high wages and more liberal import policies, the consumer goods industry shifted their locations to the periphery of Western Europe, North Africa and Turkey as well as to Asia, in the 1980s and 1990s. The production of consumer electronics disappeared completely from Western Europe. At the same time, transport costs decreased drastically due to the containerization of world trade. Trading houses now procured a large portion of their goods in Asia. ${ }^{13}$ As a result, the logistics of consumer goods distribution were realigned to import harbors, where consumer goods arrived pooled in shipping containers and container handling replaced the labor-intensive handling of cargo on the quay.

In the expansion of their terminal facilities, the ports could hardly keep up with the rapidly growing number of incoming containers. The German coffee-roasting company Eduscho (acquired in 1997 by Tchibo) that sold cheap consumer goods in their outlets pointed at the link between the import of consumer goods and container logistics. In 1993 it built a central warehouse for containers in the port Bremen and supplied from there its 22,000 outlets in Europe every week with new consumer goods. ${ }^{14}$ To meet the growing container traffic, London shifted its inner city harbor to the Thames estuary, while Hamburg's tried to defend its logistically unfavorable situation on the Elbe $100 \mathrm{~km}$ inland with ever new deepenings of the Elbe, in order to adapt the river to the rapid growth in size of container ships. From 1980, container ships that transported more than 3,000 TEUs were afloat. ${ }^{15}$ Ship beams were initially limited to $32.20 \mathrm{~m}$ because otherwise they would no longer fit through the Panama Canal, the link between the Atlantic and Pacific in Central America. Hence load capacities were limited to about 5,000 TEUs. However, the ships continued to grow despite the restrictions imposed by the Panama Canal. From 1988, yards starting building ships with over 5,000 TEU which served Europe-Asia and North America-Asia routes. In 2000, the largest ship of the Maersk shipping line, the "Sovereign Maersk", had a cargo capacity of 6,600 TEUs. Just nine years later, shipping companies were putting vessels into service with a loading capacity of 13,000 TEUs. 16 The growth in size lowered the transportation cost per container, but required large

\footnotetext{
${ }^{13}$ Levinson, Marc The Box - How the Shipping Container made the world smaller and the world economy bigger, Princeton/Oxford, 2006. Klose 2009. Taylor, D. European Distribution Strategy of Woolworth, in: Taylor, D. Global Cases in Logistics and Supply Chain Management, London 1997, p. 29-37.

${ }^{14}$ Deutsche Verkehrszeitung 8 Juni 1993.

${ }^{15}$ TEU is the conversion of container sizes to a 20-foot standard container (TEU = Twenty Foot Equivalent Unit).

${ }^{16}$ Rudolph 2009, p. 26.
} 
investments in ports to enable container handling to keep up with ship sizes. While shipping companies raked in fantastic profits, the state had to provide the necessary infrastructure with billions in investments. This unsatisfactory situation could only be changed with a pan-European container handling tax.

Globalization required special import logistics at Western Europe ports and distribution logistics linked with them via hinterland railroad transport. The northern ports of Rotterdam and Hamburg rose to become the major import harbors for containers in Europe, outdistancing ports on the Mediterranean, and achieved the position of container hubs which with feeder vessels supplied neighboring regions such as the countries on the Baltic Sea. In Hamburg, the growth in container throughput reached in the years 1995 to 2005 the considerable value of an average of 13 percent per year. ${ }^{17}$ Transport policies had not foreseen the container flood and had not made any provisions. Hinterland transport lines developed into bottlenecks of the supply chain.

Until mid-1990s, the ports on the Mediterranean failed to invest in container handling and scared off customers with high fees, rigid working hours, threats of strikes and the risk of theft. ${ }^{18}$ Container ships with consumer goods from Asia reached the Mediterranean Sea by crossing the Suez Canal, but unloaded only a small part of their containers for Germany or Austria in Trieste, Genoa or Marseille, but sailed instead two additional weeks around the Spanish peninsula to unload them in northern ports. ${ }^{19}$ The company Kombiverkehr responded to this development by offering from 1995 trains from Hamburg and Bremen to Austria for the supply of consumer goods to Austria. ${ }^{20}$ This resulted in the significant $\mathrm{CO}_{2}$ footprint of a $1000 \mathrm{~km}$ long railroad hinterland route from Hamburg to Vienna. In 1999, 66 percent of import containers destined for Austria went through northern ports and only 34 percent via Koper and Trieste..$^{21}$

\section{Conclusion: The logistic revolution}

In the 1990s, the co-occurrence of various developments caused the logistic revolution:

1. The deregulation of truck haulage markets, air traffic markets, telecommunication markets and mailing markets coincided in the 1990s and strongly affected the private supply of logistics services in the transport industry, parcel services, and telecommunication services, all of which were responsible for the management of logistic networks.

2. The consumer-oriented economy has caused an increased variety of models in materials management, and has heightened the complexity of logistical processes in production

\footnotetext{
${ }_{17}^{17}$ Winter and Katzschner 2006, p. 1165.

${ }^{18}$ While in Hamburg in 2005 container throughput increased by 15 percent, in France it fell by 1.6 percent because of strikes in Le Havre and Marseille, Verkehrsrundschau 14 March 2006.

${ }^{19}$ The Mediterranean ports developed into bottlenecks of container logistics with correspondingly high wages of dock workers, which in Piraeus reached the fantastic value of $100,000 €$ per year, roughly the level reached by container ports along the U.S. west coast.

${ }^{20}$ Vierzig Jahre Kombiverkehr, published by the Gesellschaft Kombiverkehr, 2008.

${ }^{21}$ Lecture by Professor Sebastian Kummer on the Bremen Logistics Day, 30 March 2011. Tomsic 2004.
} 
and trade. Haulers as logistics service providers have been integrated into production processes.

3. Political developments have lead to a strategic realignment of distribution systems. Both the European domestic market, the collapse of the Eastern bloc, and the establishment of a market-based national economy required a new evaluation of previous logistical concepts in purchasing and sales. In this context, we can also speak of "Euro-Logistics".

4. The concentration in food retail has grown considerably within the past years. Retail companies have built up their own specialized logistics systems.

5. Internet-based information systems, created in the 1990s, have drastically simplified and cheapened the exchange of information. They have contributed to the acceleration and precise management of material flows in the logistics supply chain. Internet-based mail order businesses have strengthened parcel services.

6. The reliability and affordability of transport processes, which accompanied the logistics revolution, has increased the division of labor between the various production stages, leading to a displacement of production sites and to their integration into supply chains. This influence of modern logistics concepts on national economies is summarized by the term "logistics effect".

The logistics revolution has been complemented theoretically by the concept of Supply Chain Management created in the 1990s, which takes the entire and probably global supply chain into account instead of optimizing an economic function just locally. With this approach, the logistic revolution has found its theoretical conclusion (Christopher 2010).

The development of logistics was up to the year 2008 a classical success story. There seemed to be no barriers against continuos expansion. But, many traffic experts saw the rise of truck traffic within Europe critical, taking the environmental costs of truck transport into account. At the same time the European Union took measures to clean the exhaustion gases of trucks (now EURO 5 norm). In the European Community a long debate arose, how to identify and to charge these costs as part of the motorway toll. But before the year 2000, in Germany one could drive a truck on a motorway without any toll. Also car drivers and the public regarded trucks as troublemakers and exerted pressure on politics to restrain trucking. The consumers demanded on the one hand a broad selection in the shops, but did not recognize, that this service was almost impossible without truck delivery - at least when the railroad did not provide service of high quality. Austria and Switzerland imposed many restrictions on Alps crossing truck traffic. The issue of "green logistics" with a broad bundle of goals to reduce the environmental impact of logistics entered the scene of traffic policy not until the year 2000 .

\section{Author details}

Richard Vahrenkamp

Department of Economics and Management, University of Kassel, Germany 


\section{References}

Bayliss, B. (1965) European Transport, Kenneth, London

Blonk, W. (1985) „Stand und Perspektiven der gemeinsamen Verkehrspolitik“, in Voigt, F., Witte, H. (Ed.) Integrationswirkungen von Verkehrssystemen und ihre Bedeutung für die EG, pp.91-102, Dunker, Berlin.

Bonino, M., Moraglio, M. (2006) Inventing Movement - History and Images of the A6 Motorway, Umberto Allemandi, Torino.

Bundesminister für Verkehr (Ed.) (1961) Die Verkehrspolitik in der Bundesrepublik Deutschland 1949-1961, Kirschbaum, Bielefeld.

Campbell, James (2001) The Rise of Global Delivery Services: A Case Study in International Regulatory Reform, JCampbell Press, no location.

Cecchini, P. (1988) Europa 1992, Nomos, Baden-Baden.

Charlesworth, G. (1984) A History of British Motorways, Telford, London.

Christopher, M. (2010) Logistics and Supply Chain Management, Prentice Hall, Harlow.

European Conference of Ministers of Transport (ECMT) (Ed.) (1985) Improvements in international railway transport services, OECD Publishing Office, Paris.

European Commission (Ed.) (2001) Road Freight Transport for Own Account in Europe, ECMT, Paris.

Europäische Kommission (Ed.) (1983) „Fortschritte auf dem Wege zu einer gemeinsamen Verkehrspolitik“, Amtsblatt der Europäischen Gemeinschaften, Nr. C 154, pp. 1-21.

Eurostat (1989) Europa in Zahlen, Amt für amtliche

Veröffentlichungen der Europäischen Gemeinschaften, Luxemburg.

Eurostat (2002a) „Die Entwicklung des Güterkraftverkehr 1990-1999“, in Statistik kurzgefaßt, Luxemburg, issue 2.

Eurostat (2002b) „Das Wichtigste aus dem Panorama des Verkehrs 1970-1999“, in Statistik kurzgefaßt, Luxemburg, issue 3.

Frerich, J. (1974) Die regionalen Wachstums- und Struktureffekte von Autobahnen in Industrieländern, Dunker, Berlin.

Frerich, J., Müller, G. (2004) Europäische Verkehrspolitik. Von den Anfängen bis zur Osterweiterung. vol. 2: Landverkehrspolitik, Oldenbourg München.

Girnth, Walter (1954) Chaos oder Ordnung? Alarm im westdeutschen Verkehr, Athenäum, Bonn.

Gourvish, Terry (2006) The Official History of Britain and the Channel Tunnel, Routledge Chapman, London.

Héritier, A. et al. (Eds.) (2001) Differential Europe, Rowman \& Littlefield, Oxford.

Judt, Tony (2005) Postwar: A history of Europe since 1945, The Penguin Press, New York.

Kerwer, D. (2001) "Going trough the Motions: The modest impact of Europe on Italian Transport Policy", in Adrienne Héritier u. a. (Eds.) Differential Europe, pp. 173-216, Rowman\&Littlefield, Oxford.

Klenke, D. (1993) Bundesdeutsche Verkehrspolitik und Motorisierung: Konfliktträchtige Weichenstellungen in den Jahren des Wiederaufstiegs, Steiner, Stuttgart.

Laaser, Friedrich (1991) Wettbewerb im Verkehrswesen: Chancen für eine Deregulierung in der Bundesrepublik, Mohr, Tübingen. 
Levinson, M. (2006) The Box - How the Shipping Container made the world smaller and the world economy bigger, Princeton UP, Princeton.

Loubet, J.-L. (2001) Histoire de L'Automobile Francaise, Seuil, Paris.

Lundin, P. (2004) "American Numbers Copied! Shaping the Swedish Postwar Car Society", Comparative Technology Transfer and Society, 2, 3, pp. 303-337.

Merriman, Peter: Driving spaces. A cultural-historical geography of England's M1 motorway, Malden, Mass.: Blackwell, 2007.

Mom, G. (2 005) "Roads without Rails - European Highway-Network Building and the Desire for Long-Range Motorized Mobility", Technology \& Culture, 46, 4, pp. 745-772.

Paolini, F. (2005) Un paese a quattro ruote. Automobili e società in Italia, Marsilio, Venezia.

ReVelle, Charles and Ralph Swain (1970) "Central Facility Location", in: Geographical Analysis, 2, pp. 30-42

Ross, J. (1998) Linking Europe. Transport Policies and Politics in the European Union, Praeger, Westport.

Schipper, Frank (2007) "Changing the Face of Europe: European Road Mobility during the Marshall Plan Years", The Journal of Transport History, 28, 2, pp. 211-228.

Schipper, Frank (2008) Driving Europe - Building Europe on Roads in the Twentieth Century, Aksant, Amsterdam.

Stone, B. (2003) “Interoperability: How railway became European”, in: Burri, M., Elsasser, K. T. and Gugerli, D. (Eds.), Die Internationalität der Eisenbahn 1850-1970, pp. 237-244, Chronos, Zurich.

Strasser, Susan (1998) Getting and spending : European and American consumer societies in the twentieth century, Cambridge Univ. Press, Cambridge.

Thoms, D., Holden, L. and Claydon, T. (1998) The motor car and popular culture in the 20th century, Ashgate, Aldershot.

Tomsic, Mojca: Interconnectivity of Ports and Railways - A Comparison of three Ports in neighbouring Countries: Trieste (Italy), Koper (Slovenia) and Rijeka (Croatia), in: HansLiudger Dienel (ed.): Unconnected Transport Networks. European Intermodal Traffic Junctions, 1800-2000, Frankfurt 2004, pp. 139-160.

Trinkaus, K., Maiworm, R., Joseph, K. and Vorrath, E. (Eds.) (1998) Güterkraftverkehrsrecht: Systematische Sammlung der Gesetze, Verordnungen und Verwaltungsvorschriften für den nationalen und internationalen Güterkraftverkehr sowie Kommentar zum Güterkraftverkehrsgesetz und ergänzenden Vorschriften, $4^{\text {th }}$ edition, E. Schmidt, Berlin.

Tronet, V. (2002) Das Wichtigste aus dem Panorama des Verkehrs 1970-1999, Eurostat, Statistik kurzgefaßt, Luxembourg, issue 3, p. 3.

Vahrenkamp, Richard: The Logistic Revolution - The Rise of Logistics in the Mass Consumption Society, Cologne 2012.

Winter, Horst und Thomas Katzschner: Containerumschlag deutscher Seehäfen 1995 bis 2005, in: Wirtschaft und Statistik, Heft 11, 2006, pp. 1159 - 1167.

World Road Congress (1969) AIPCR-PIAC 1909-1969, Editions Science et Industrie, Paris. 